\title{
A NORTHERN HEMISPHERE VOLCANIC CHEMISTRY RECORD (1869-1984) AND CLIMATIC IMPLICATIONS USING A SOUTH GREENLAND ICE CORE
}

by

\author{
W.B. Lyons, P.A. Mayewski, M.J. Spencer, M.S. Twickler,
}

(Glacier Research Group and Institute for the Study of Earth, Oceans and Space,

University of New Hampshire, Durham, NH 03824, U.S.A.)

and

\section{T.E. Graedel}

(ATT Bell Laboratories, Murray Hill, NJ 07974, U.S.A.)

\section{ABSTRACT}

The effect of volcanic emission of acidic aerosols on climate is well documented. The presence of acid droplets in the stratosphere can reduce transmissivity and hence decrease surface temperatures. Since the amount and chemical composition of erupted material has important effects on regional climate, knowledge of past volcanic events is of extreme importance. Detailed glaciochemical records provide the only milieu wherein the geochemistry of paleovolcanic events can be fully documented. We present a detailed sulfate and chloride record from an ice core drilled at site $20 \mathrm{D}, 40 \mathrm{~km} \mathrm{SW}$ of Dye 3 in southern Greenland. The record spans the time period 1869-1984 with chemical analyses of approximately eight samples per year. Time series decomposition and locally weighted scatter plot smoothing techniques were used to extract long term trends from the data so that individual volcanic eruptions could be documented. A number of events identified here have been unnoticed previously and a high percentage of the major chemical signatures documenting these events is associated with large decreases in temperature in the latitudinal zone $60-90^{\circ} \mathrm{N}$. Many authors have pointed out that the amount of volcanic acids such as $\mathrm{HCl}$ and $\mathrm{H}_{2} \mathrm{SO}_{4}$ injected into the atmosphere has a very important influence on global climate, yet this volcanic input has been difficult to quantify prior to $\sim 1960$. Our data help to alleviate this problem. These individual events can be compared to available frost tree ring data from North America, further establishing a volcanism-climatic linkage.

\section{INTRODUCTION}

The effect of volcanic emission of aerosols into the atmosphere on climate is well documented (Lamb, 1970; Pollack and others, 1976; Self and others, 1981; Rampino and Self, 1982, 1984; Sear and others, 1987, Self and Rampino, 1988). Large amounts of volcanic debris introduced into the stratosphere between 1500 and 1900 may have played a causative role in the "Little Ice Age" of this period (Lamb, 1970). Major explosive volcanic events such as Tambora (1815) and Krakatau (1883) produced a consistent but small temperature decrease on a hemispheric scale for periods up to five years (Self and others, 1981). Even smaller eruptions such as Agung (1963) produced similar temperature perturbations (Self and others, 1981). It has been suggested that volcanic emissions of sulfur and halogen aerosols may have more effect on climatic change than that of volcanic dust (Pollack and others, 1976; Rampino and Self, 1982). The presence of acid droplets in the stratosphare can reduce transmissivity and hence decrease surface temperatures. Thus, smaller sulfur- and halogen-rich eruptions may have more pronourced climatic effects than larger less halogen-rich eruptions (Rampino and Self, 1984). This may be especially true in the Northern Hemisphere (Sear and others, 1987). Since the amount and chemical composition of erupted material have an important effect on regional and global climate, knowledge of past volcanic events and of the geochemical signature of the aerosol is of extreme importance. Detailed glaciochemical records provide the best milieu wherein the glaciochemistry of paleovolcanic events can be documented.

Although other types of information are available to establish the chronology and the volume of the past volcanic events (Lamb, 1970; Simkin and others, 1981) these data sets are incomplete (Self and others, 1981). In fact, Sedlacek and others (1983) have shown through an in-situ stratospheric sampling program that, as late as the 1970s, many volcanic eruptions that influence the chemistry of the stratosphere went unreported. Therefore, past records of volcanic events affecting stratospheric chemistry and hence the climate are undoubtedly incomplete. In addition, there have been very few eruptions from which sufficient data exist to develop quantitative estimates of the mass of materials introduced into the atmosphere (Self and others, 1981; Devine and others, 1984).

It has long been acknowledged that volcanic emissions are an important source of several chemical species to the atmosphere. Yet it has been extremely difficult to evaluate the qualitative let alone quantitative role of volcanic emissions. Although volcanic injection of acidic anions and sulfur dioxide into the atmosphere is episodic, Sedlacek and others (1983) have shown that the volcanic contribution to the stratospheric sulfate concentration over the period 1971-81 was $\sim 60 \%$. In addition, stratospheric volcanic $\mathrm{Cl}^{-}$ emissions may be greatly under-estimated (Johnson, 1980). Both Neftel and others (1985) and Barrie and others (1985), utilizing ice core data from southern Greenland and Ellesmere Island, respectively, have argued that there is a strong background acid contribution to Arctic snow during the past $\sim 80$ years that cannot be accounted for by anthropogenic emissions. Previous work has demonstrated that volcanic events can be documented in Arctic ice cores (Table I).

\section{ANALYTICAL METHODS AND PROCEDURES}

In June 1984 we obtained a $\sim 115 \mathrm{~m}$ core from site $20 \mathrm{D}, \sim 40 \mathrm{~km}$ southwest of Dye $3\left(65.01^{\circ} \mathrm{N}, 44.87^{\circ} \mathrm{W}\right.$, $2615 \mathrm{~m}$ a.s.1.). The top $71 \mathrm{~m}$ of this core has been analyzed in detail to produce an anthropogenic deposition record for $\mathrm{SO}_{4}^{2-}$ and $\mathrm{NO}_{3}^{-}$in southern Greenland (Mayewski and others, 1986). Measurements of $\mathrm{Cl}^{-}, \mathrm{Na}^{+}$and $\delta^{18} \mathrm{O}$ concentrations were also made while selected core sections were also analyzed for $\mathrm{NH}_{4}^{+}$and $\mathrm{F}^{-}$. Anions were analyzed using a Dionex $^{\text {TM }}$ Model $^{4} 2010$ ion chromatograph with a AS-4 
TABLE I. VOLCANIC EVENTS (1870-1984) DOCUMENTED IN ARCTIC ICE CORES PRIOR TO THIS WORK

\begin{tabular}{|c|c|c|c|}
\hline Event & $\begin{array}{l}\text { Location of } \\
\text { the sample }\end{array}$ & Technique* & Reference \\
\hline \multirow[t]{5}{*}{ Katmai, 1912} & Crête & LC & Hammer, 1977 \\
\hline & Dye 3 & SC & Nef tel and others, 1985 \\
\hline & Hans Tavsen Ice Cap & LA, SC & Hammer, 1980 \\
\hline & Mt. Logan & AN & Holdsworth and Peake, 1985 \\
\hline & Ellesmere Island & LC & Barrie and others, 1985 \\
\hline \multirow[t]{3}{*}{ Krakatau, 1983} & Crête & LC & Hammer, 1977 \\
\hline & & SC & Hammer and others, 1980 \\
\hline & Dye 3 & AN & Herron, 1982 \\
\hline Bandai, 1888 & Dye 3 & AN & Herron, 1982 \\
\hline Hekla, 1947 & Crête & SC & Hammer and others, 1980 \\
\hline Mt. Trident, 1961 & Baff in Island & LC & Holdsworth, 1984 \\
\hline Agung, 1963 & Crête & LC & Hammer, 1977 \\
\hline Katla, 1918 & Mt. Logan & AN & Holdsworth and Peake, 1985 \\
\hline Mt. Wrangell, 1922 & Mt. Logan & AN & Holdsworth and Peake, 1985 \\
\hline Raikoke, 1924 & Mt. Logan & AN & Holdsworth and Peake, 1985 \\
\hline St. Augustine, 1934 & Mt. Logan & AN & Holdsworth and Peake, 1985 \\
\hline Kliuchevskoi, 1937 & Mt. Logan & AN & Holdsworth and Peake, 1985 \\
\hline St. Augustine, 1976 & Mt. Logan & AN & Holdsworth and Peake, 1985 \\
\hline
\end{tabular}

${ }^{*} \mathrm{LC}=$ liquid conductivity, $\mathrm{SC}=$ solid conductivity, $\mathrm{A}=$ liquid acidity, $\mathrm{AN}=$ anionic analysis

column. Sodium was analyzed via stabilized temperature platform furnace atomic absorption spectrometry using a Perkin Elmer ${ }^{\mathrm{TM}}$ Model 2280 system. The chronology assigned to the $\delta^{18} \mathrm{O}$ record was calibrated using known bomb layers in the total $\beta$-activity record from the upper $18 \mathrm{~m}$ of the core. In addition, cross-correlation of $\delta^{18} \mathrm{O}$ from a core located $4 \mathrm{~km}$ to the northeast of our core site produced by the University of Copenhagen group was also used to determine depth-age relations. This glaciochemical record is one of the most detailed ever obtained with 6-8 analyses per year for a continuous 115 years. Less frequent sampling would probably not allow the observations of many of these signals.

\section{RESULTS OF VOLCANIC INPUTS TO $20 \mathrm{D}-1869$ TO 1984}

Herron and others (1981) have shown that at Dye 3 from 1960-79 $\sim 8 \%$ of the annual snow accumulation had melted and refrozen. However, the work of Herron (1982) and Koide and Goldberg (1985) indicates that Dye 3 snows are good preservers of volcanic records as well as of nuclear weapon testing records.

In order to reduce the potential effects of acid anion redistribution via melting/freezing we attempted to avoid ice lenses during core processing. However, the sampling of ice lenses could not always be avoided, so that the samples corresponding to years in which the percentage of ice lenses (determined from our visible observations) was greater than $10 \%$ have been eliminated from the volcanic assessment. These years are listed in Table II.

"Potential" volcanic events from site $20 \mathrm{D}$ core were chosen by the criteria listed in Table III. In addition, time series decomposition and locally weighted scatter plot smoothing analysis (Cleveland, 1979; Cleveland and Terpenning, 1981) of the total excess $\mathrm{SO}_{4}^{2-}$ record with the historic trend removed provide a clear view of the signals

TABLE II. YEARS WHEN ANNUAL MELT PERCENTAGE WAS GREATER THAN 10\% OF ANNUAL ACCUMULATION

$1886,1887,1888$

$1890,1894,1896$

1943

1904,1906

1926

1935,1939
1951,1957

1969

1971,1978

1982
TABLE III. CRITERIA FOR CHOOSING VOLCANIC EVENTS

Constituents Criterion

$\begin{aligned} \mathrm{Cl}^{-} & >42 \mu \mathrm{gg}^{-1} \text { or double "background" } \\ & \text { of } 20 \mu \mathrm{gg}^{-1} \\ \mathrm{SO}_{4}^{2-} & >52 \mu \mathrm{gg}^{-1} 1869-1900 \\ & >104 \mu \mathrm{gg}^{-1} 1900-60 \\ & \text { or double "background" } \\ & >222 \mu \mathrm{gg}^{-1} 1960-64 \\ & \text { or triple "background" } \\ & \text { (see Mayewski and others, 1986, for } \\ & \text { how "background" was estimated) }\end{aligned}$

above the background (i.e. residuals). This approach allows a visible observation of these strong deviations from the historical trend and supports our more qualitative approach at picking volcanic peaks. Potential volcanic events are tabulated in Tables IV and V. The $\mathrm{NO}_{3}^{-}$concentrations associated with many of these potential events (Tables IV-VI) will not be discussed here. In addition to the total $\mathrm{Cl}^{-}$values presented in Table IV we have also presented "excess" $\mathrm{Cl}^{-}$. This parameter is calculated like excess $\mathrm{SO}_{4}^{2-}$ using the $\mathrm{Na}^{+}$data and the $\mathrm{Na}^{+}: \mathrm{Cl}^{-}$ratio of seawater to calculate the amount of $\mathrm{Cl}^{-}$present in the sample that is not associated with sea salt. The volcanic $\mathrm{Cl}^{-}$question is complicated due to the fact that the volcanic $\mathrm{Cl}^{-}$present could be in the form of $\mathrm{HCl}$ or $\mathrm{NaCl}$ (Woods and others, 1985). There is little doubt that certain volancoes may emit more $\mathrm{Cl}^{-}$than $\mathrm{So}_{4}^{2-}$ during their explosive stage (Devine and others, 1984).

Volcanic loading is dependent on, in addition to other variables, source strength and the duration of the eruption. Hammer (1977) has suggested that it is possible to have a one-year lag between a volcanic eruption south of $50^{\circ} \mathrm{N}$ and the subsequent deposition of its aerosol products in Greenland. Two- and three-year lags have been shown for near-equatorial volcanic events (Herron, 1982). In addition to these considerations, volcanic events south of $20^{\circ} \mathrm{S}$ are unlikely to be observed in Greenland ice (Hammer, 1977; Hammer and others, 1980).

Although volcanic emissions of $\mathrm{Cl}^{-}$and $\mathrm{F}^{-}$can be quantitatively important to the global atmosphere (Cadle, 1980; Symonds and others, 1988), only through stratospheric emission and/or through tropospheric transport from a North American volcano is it likely that substantial amounts of 
TABLE IV. VOLCANIC $\mathrm{Cl}^{-}$SIGNALS AT $20 \mathrm{D}$

\begin{tabular}{|c|c|c|c|c|c|}
\hline Year & Time of year* & $\begin{array}{c}\mathrm{Cl}^{-} \\
\left(\mu \mathrm{g} \mathrm{kg}^{-1}\right)\end{array}$ & Excess $\mathrm{Cl}^{-}$ & $\begin{array}{l}\text { Other } \\
\text { excesses }\end{array}$ & Event \\
\hline 1984 & winter/spring & 260 & 0 & $\mathrm{SO}_{4}^{2-}$ & El Chichon \\
\hline $\begin{array}{l}1981 \\
1979\end{array}$ & spring/summer & 55 & 0 & $-{ }^{2}$ & Mt. St. Helens, Garelo, Ulawu \\
\hline 1979 & winter/spring & 46 & 8 & - & $\begin{array}{l}\text { major undocumented strato- } \\
\text { spheric injection }\end{array}$ \\
\hline 1978 & winter/spring & 51 & 6 & - & Benzymianny \\
\hline 1963 & spring & 93 & 18 & - & Surtsey \\
\hline 1959 & winter/spring & 190 & 5 & - & Chikurachki-Tatan \\
\hline 1954 & winter/spring & 57 & 0 & $\mathrm{NO}_{3}^{-}$ & Mt. Spur \\
\hline 1950 & fall & 143 & 0 & - & $?$ \\
\hline \multirow[t]{4}{*}{1947} & winter $\rightarrow$ summer & 53 & 11 & - & Hekla \\
\hline & & 180 & 29 & $\mathrm{~F}^{-}$ & Hekla \\
\hline & & 60 & 11 & - & Hekla \\
\hline & & 48 & 10 & - & Hekla \\
\hline $\begin{array}{l}1945 \\
1942\end{array}$ & winter/spring & 47 & 11 & - & Cleveland? \\
\hline $\begin{array}{l}1942 \\
1941\end{array}$ & fall/winter & 110 & 1 & - & Cotopaxi, Paulo \\
\hline $\begin{array}{l}1941 \\
1941\end{array}$ & fall/winter & 190 & 0 & - & $?$ \\
\hline \multirow[t]{2}{*}{$1936-37$} & spring & 51 & 23 & $\mathrm{SO}_{4}^{2-}$ & ?Grimsvötn \\
\hline & winter & 63 & 6 & - & Asama, Magesh, Kliuch \\
\hline 1936 & summer & 56 & 8 & - & \\
\hline 1933 & $\begin{array}{l}\text { summer } \\
\text { fall/winter }\end{array}$ & 63 & 6 & - & Asama \\
\hline \multirow[t]{2}{*}{$1930-31$} & fall/winter & 80 & 13 & - & Fuego, Quiza \\
\hline & & $\begin{array}{l}52 \\
64\end{array}$ & 14 & - & Sarych \\
\hline 1930 & spring & $\begin{array}{r}64 \\
400\end{array}$ & 12 & $\mathrm{SO}_{-}^{2-}$ & $\begin{array}{l}\text { Palmch? Sarych } \\
\text { Mt. Peleé or Ko? }\end{array}$ \\
\hline 1929 & spring & $\begin{array}{r}400 \\
52\end{array}$ & $\begin{array}{r}383 \\
13\end{array}$ & $\overline{-}$ & $\begin{array}{l}\text { Mt. Peleé or Ko? } \\
\text { Palmeh }\end{array}$ \\
\hline 1928 & spring & $\begin{array}{r}52 \\
100\end{array}$ & $\begin{array}{l}13 \\
28\end{array}$ & $\begin{array}{l}- \\
-\end{array}$ & $\begin{array}{l}\text { Palmeh } \\
\text { Multiple activity }\end{array}$ \\
\hline \multirow{3}{*}{1925} & fall/winter & & & & Kuryils, Japan \\
\hline & & 49 & 4 & - & Galeras? or \\
\hline & & $\begin{array}{l}48 \\
47\end{array}$ & $\begin{array}{l}8 \\
8\end{array}$ & - & Raikoke? \\
\hline \multirow[t]{2}{*}{1922} & summer/fall & 64 & $\begin{array}{l}8 \\
5\end{array}$ & - & \\
\hline & & 50 & $\begin{array}{l}5 \\
4\end{array}$ & $\begin{array}{l}- \\
-\end{array}$ & Mt. Wrangell \\
\hline 1921 & winter/spring & 46 & 6 & $\mathrm{SO}_{4}^{2-}$ & ?Manam \\
\hline 1920 & winter/spring & 71 & 9 & - & $\begin{array}{l}\text { ?Manam } \\
\text { Kumagatake, Asama }\end{array}$ \\
\hline 1917 & spring/summer & 283 & 2 & & $\begin{array}{l}\text { Kumagatake, Asana } \\
\text { ? }\end{array}$ \\
\hline 1913 & winter/spring & 54 & 5 & & $\begin{array}{l}\text { Katmai, } 1913 \text { eruption } \\
\text { near Hekla }\end{array}$ \\
\hline 1911 & winter/spring & 115 & 7 & & Japan, Aleutians, Kamchatka \\
\hline 1906 & winter/spring & 101 & 0 & & Japan \\
\hline 1903 & fall & 120 & 0 & $\mathrm{SO}_{4}^{2-}$ & Santa Maria, Thordarhyn \\
\hline 1902 & fall/winter & 53 & 0 & & Mt. Peleé, Souf rière \\
\hline 1901 & winter/spring & 53 & 0 & & Dona Juana? Adatano \\
\hline 1898 & winter/spring & 100 & 0 & & Mayon? \\
\hline 1896 & fall/winter & 47 & 0 & & Bandai? Bogoslof \\
\hline 1890 & winter/spring & 84 & 0 & & Shiretoko Iwo Zan \\
\hline 1885 & winter/spring & 65 & 0 & & Krakatau? \\
\hline \multirow[t]{2}{*}{1880} & winter/spring & 81 & 7 & & $?$ \\
\hline & & 50 & 2 & & $?$ \\
\hline \multirow[t]{2}{*}{1879} & winter/spring & 102 & 0 & & $\begin{array}{l}\text { Cotopaxi?, } 1878 \text { eruption } \\
\text { near Hekla }\end{array}$ \\
\hline & & 238 & 29 & $\mathrm{SO}_{4}^{2-}$ & $?$ \\
\hline 1876 & fall & 65 & 5 & & $?$ \\
\hline 1874 & fall & 130 & 35 & & Tarumai? \\
\hline 1873 & winter/spring & 89 & 15 & $\mathrm{SO}_{4}^{2-}$ & Grimsvötn \\
\hline 1871 & winter/spring & 66 & 13 & $\mathrm{SO}_{4}^{2-}$ & Cotopaxi? \\
\hline
\end{tabular}

Volcanic events taken from Hoyt, 1979; Simkin and others, 1982; Sedlacek and others, 1983.

* From $\delta^{18} \mathrm{O}$ profiles.

volcanic $\mathrm{Cl}^{-}$and $\mathrm{F}^{-}$would reach Greenland. Recent work using in-situ techniques have established volcanic stratospheric inputs of both $\mathrm{HCl}$ and $\mathrm{NaCl}$ (Lazrus and others, 1979; Woods and other, 1985). This is an important consideration in establishing volcanic $\mathrm{Cl}^{-}$records in ice cores. In only two events is the excess $\mathrm{Cl}^{-} \approx 50 \%$ of the total $\mathrm{Cl}^{-}$measured. These events are the 1930 and the 1941 $\mathrm{Cl}^{-}$spikes. We have interpreted the 1941 spike to be the eruption of Grimsvötn, Iceland, while the 1930 event is unknown. The 1930 spike represents a massive injection of excess $\mathrm{Cl}^{-}$onto the southern Greenland ice sheet. It is curious that no extremely large eruption is documented in late 1929 or early 1930 to explain this signal. In addition, the $\mathrm{Cl}^{-}$peak is preceded by a very large $\mathrm{NO}_{3}^{-}$signal in late 1929 (Table VI). There is no associated excess $\mathrm{SO}_{4}^{2-}$ event. It is possible that these peaks are due to the Komaga-Take eruption in Japan in 1929. However, 1947 Hekla and 1963 Surtsey have only $\sim 20 \%$ of their total $\mathrm{Cl}^{-}$ recorded at $20 \mathrm{D}$ as excess $\mathrm{Cl}^{-}$. This would suggest that the 1930 event could have been a nearby Icelandic eruption, for it appears that the majority of volcanic $\mathrm{HCl}$ reaching southern Greenland is usually neutralized during transit. It is probable that much of the stratospheric gaseous $\mathrm{Cl}^{-}$is also neutralized in transit to southern Greenland. 
TABLE V. VOLCANIC $\mathrm{SO}_{4}^{2-}$ SIGNALS AT $20 \mathrm{D}$

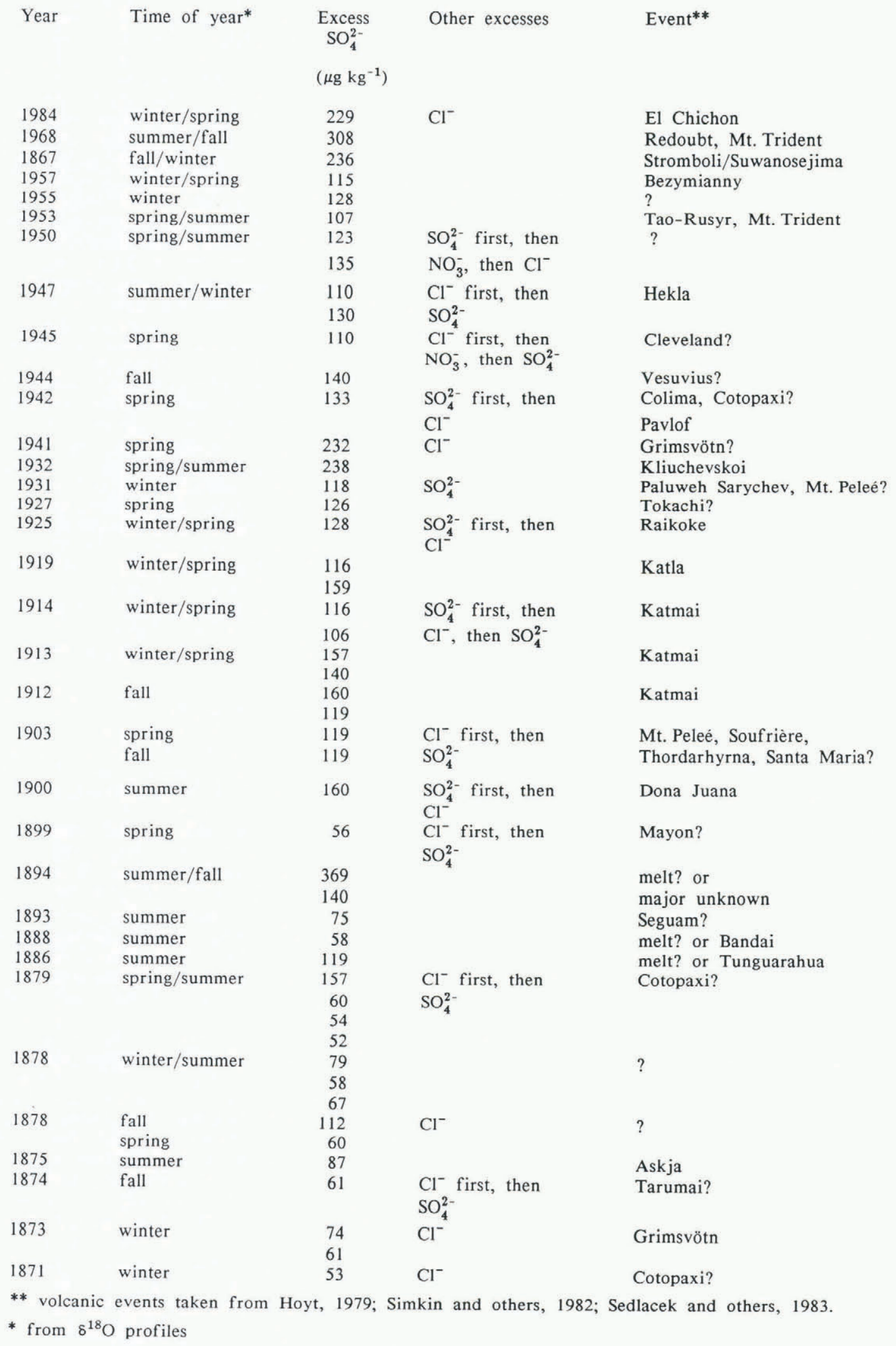

The major $\mathrm{Cl}^{-}$events observed at site $20 \mathrm{D}$ include the Hekla, Grimsvötn and 1929-30 eruptions mentioned above, as well as Cotopaxi (1878), Agrigian (1917), Chikurachki (1959) and the most recent El Chichon eruptions (Mayewski and others, 1987). There is also an undocumented 1950 event.

Fluoride measurements have also been undertaken on many of these samples. Only in the two core segments was $\mathrm{F}^{-}$detected as greater than $1 \mu \mathrm{g} \mathrm{kg}^{-1}$. Our results indicate that in only a very few limited cases does HF contribute to the volcanic input of acid to southern Greenland during the period 1869-1984. Our maximum $\mathrm{F}^{-}$concentrations are much lower than were previously reported by Herron (1982). Only after the eruptions of Hekla (1947) and Katmai (1912), the two most obviously reconizable volcanic events in the 115 year record (Tables IV-VI), do we measure any $\mathrm{F}^{-}$. The major $\mathrm{SO}_{4}^{2-}$ signals include the 1894 , 1941, 1967, 1968, and 1984 events. (The 1984 has been previously interpreted as El Chichon by Mayewski and others, 1987.) 


\section{DISCUSSION}

It is clear from this work and that of Holdsworth and Peake (1985), Delmas and others (1985a) and Legrand and Delmas (1987) that only through detailed anionic analyses along with precise and accurate dating can volcanic records such as these be produced from ice cores. The events with both $\mathrm{Cl}^{-}$and $\mathrm{SO}_{4}^{2-}$ peaks and in some cases $\mathrm{Cl}^{-}, \mathrm{SO}_{4}^{2-}$ and $\mathrm{NO}_{3}^{-}$peaks are indeed volcanic signatures. These eruptions are listed in Table VI.

\section{TABLE VI. $20 \mathrm{D}$ VOLCANIC EVENTS}

\begin{tabular}{llll} 
Both $\mathrm{Cl}^{-}$ & and $\mathrm{SO}_{4}^{2-}$ events & $\mathrm{Cl}^{-}, \mathrm{SO}_{4}^{2-}$ and $\mathrm{NO}_{3}^{-}$events \\
1871 & $?$ & 1879 & Cotopaxi? \\
1874 & Tarumai? & 1917 & Agrigan? \\
1876 & Askja? & 1945 & Cleveland? \\
$1898-99$ & Mayon? & 1950 & $?$ \\
1900 & Dona Juana \\
1903 & Mt. Peleé, Souf rière \\
\multicolumn{4}{c}{} \\
$1912-14$ & Katmordarhyrna \\
1925 & Raikoke Hekla \\
1931 & Paluweh? \\
1941 & Grimsvötn?, or low-latitude \\
\multicolumn{3}{c}{ unknown event (see text) } \\
1942 & Colima? Cotopaxi? \\
1947 & Hekla \\
1954 & Mt. Spurr \\
1984 & El Chichon
\end{tabular}

Holdsworth and Peake (1985) have also observed the eruptions of Katla (1918-19), Raikoke (1924-25) and Hekla (1947) via detailed anion analysis from an ice core from Mt. Logan, Canada. These workers have also detected eruptions that are not clearly evident from our data. They include Mt. Wrangell (1922), St. Augustine (1934-35) and Kliuchevskoi (1937-38).

Are there any other data to support our contention that these chemical signals are volcanic events? Although not explicit in their work, data sets of both Neftel and others (1985) and Barrie and others (1985) have corroborated many of our volcanic signals. In the Neftel and others (1985) data from Dye 3, years when the averaged $\mathrm{SO}_{4}^{2-}$ data lie well above their spline-smoothed curve are shown in Table VI. For the Barrie and others (1985) data from a core from Ellesmere Island, Canada, we have taken their conductivity data for years that show two peaks per year instead of the usual single peak per year (i.e. one of these peaks is presumed to be volcanic), as well as years with extremely high single peaks. (This was done by comparing peaks to adjoining year data.) These years are also listed in Table VII. It cannot be circumstantial that there is good agreement among the different data sets. Although all the data are not always in exact agreement (i.e. \pm 1 year), this comparison of data sets supports our contentions of volcanic events

TABLE VII. COMPARISON OF VOLCANIC EVENTS BETWEEN OUR WORK AND THAT OF NEFTEL AND OTHERS (1985) AND BARRIE AND OTHERS (1985). (SEE TEXT FOR EXPLANATION)

$\begin{array}{lcl}\text { Our work } & \begin{array}{c}\text { Neftel and } \\ \text { others }\end{array} & \begin{array}{c}\text { Barrie and } \\ \text { others }\end{array} \\ 1903 \text { - Mt. Peleé, Souf rière } & 1903 & \text { ND } \\ 1906 \text { - melt event? } & 1906 & \text { ND } \\ 1912-14 \text { - Katmai } & 1912-13 & 1912 \\ 1917 \text { - ? } & 1917 & 1916 \\ 1925 \text { - Raikoke } & 1924 & 1924-25 \\ 1931 \text { - Paluweh? } & 1930 & 1931,1933 ? \\ 1941 \text { - ? } & 1941 & 1940 \\ 1942 \text { - ? } & 1943 & 1943\end{array}$

$\mathrm{ND}=\mathrm{No}$ data being recorded in glacier ice and snow throughout the Arctic region.

Other types of information such as atmospheric transmission measurements at Table Mountain, California (the Smithsonian Astrophysical Observatory) indicate that such Southern Hemispheric eruptions as Paluweh (1928) and Quizapu (1932) were easily observed in the mid-latitudes of the Northern Hemisphere (Hoyt, 1979). These eruptions can also be documented in the $20 \mathrm{D}$ core (Tables IV-V).

Notably there are eruptions that we cannot document at site $20 \mathrm{D}$ which one might expect to have been recorded. For example, we do not detect Agung (1963). Interestingly enough neither Delmas and others (1985b) nor Koerner and Fisher (1982), respectively, observed it at Mt. Logan and the Agassiz Ice Cap, Canada. Eighty per cent of the volcanic debris injected by the Agung eruption remained in the Southern Hemisphere (Delmas and others, 1985a; Self and Rampino, 1988). Self and Rampino (1988) have recently argued that the estimate by Hammer and others (1980) of Agung fallout in southern Greenland is too high. Our data support this contention. Our data interpretation also agrees with their idea that some of the acid measured by Hammer and others (1980) in 1963 could be related to the Surtsey eruption (see Table IV, especially excess $\mathrm{Cl}^{-}$). Although we observe what could possibly be a small $\mathrm{Cl}^{-}$excess due to the Krakatau eruption (1883) (Table V), its significance in the $20 \mathrm{D}$ record is small. Delmas and others (1985a) have argued that both Agung and Krakatau should probably not be detected in Greenland ice. Our data also show little to no effect in southern Greenland of the Mt. St. Helens (1980) eruption. We observe a small $\mathrm{Cl}^{-}$signal (Table IV) but no $\mathrm{SO}_{4}^{2-}$ signal. This is not surprising because this eruption was very poor in $\mathrm{H}_{2} \mathrm{SO}_{4}$ but relatively rich in halogens. As Self and Rampino (1988) state, "in terms of climate Mt. St. Helens was a non-event". Our data support this premise.

\section{CLIMATIC IMPLICATIONS}

Probably the most significant aspect of this work is the climatic implications. Volcanic aerosols can be major contributors to regional and global temperature changes both in the long- and short-term (Lamb, 1970; Pollack and others, 1976; Bradley and England, 1978; Self and others, 1981; Rampino and Self, 1982, 1984; Stothers, 1984). Eruptions such as Tambora (1815), Krakatau (1883), Santa Maria (1902), Katmai (1912), and Quizapu (1932) have produced temperature decreases on the order of $0.2-0.5^{\circ} \mathrm{C}$ on a hemispheric scale for time periods up to five years (Self and others, 1981). The temperature perturbations due to volcanic aerosol emission may reach as high as $1.5^{\circ} \mathrm{C}$ (in earth surface temperatures) in the high-latitude zones (Self and others, 1981).

The average yearly $\Delta \mathrm{T}^{\circ}$ from 1875 to 1977 in the latitudinal zone $60^{\circ} \rightarrow 90^{\circ} \mathrm{N}$ tabulated by Self and others (1981) is shown in Figure 1. Their arrows indicate the eruptions of Krakatau, Santa Maria + Peleé + Soufrière, Katmai, Hekla, Bezymianny and Agung were followed by rapid decreases in $\Delta \mathrm{T}^{\circ}$. Using the data presented within, not only do the Santa Maria + Peleé + Soufrière, Katmai and Hekla volcanic signals documented in southern Greenland correspond to $\Delta \mathrm{T}$ drops, but at least eight other volcanically associated $\Delta \mathrm{T}$ decreases can also be observed (Fig. 1). The $\Delta \mathrm{T}^{\circ}$ decrease Self and others (1981) have associated with Bezymianny might actually be associated with the Mt. Spurr eruption of 1954. Many of the decreases in $\Delta \mathrm{T}$ between $1884-85$ to 1902 may also be volcanically induced but our data from this period are not as convincing (i.e. only $\mathrm{Cl}^{-}$or $\mathrm{SO}_{4}^{2-}$ spikes, not both or the dates of $\Delta \mathrm{T}^{8}$ drops and Greenland ice core signals are offset by a year or more). The decrease of $\Delta \mathrm{T}^{\circ}$ after 1960 may also be volcanically related but the $\mathrm{SO}_{4}^{2-}$ anthropogenic record probably makes it. This dramatic coincidence of $\Delta \mathrm{T}^{\circ}$ drop above $60^{\circ} \mathrm{N}$ latitude and volcanic acid input observed in southern Greenland snow and ice is probably not coincidental. It is our supposition that the volcanic eruptions documented in the ice core indicate a possible cause and effect relationship resulting in small but significant temperature decreases.

The argument is further substantiated by measured decreases in $\delta^{18} \mathrm{O}$ of snow after the deposition of volcanic 


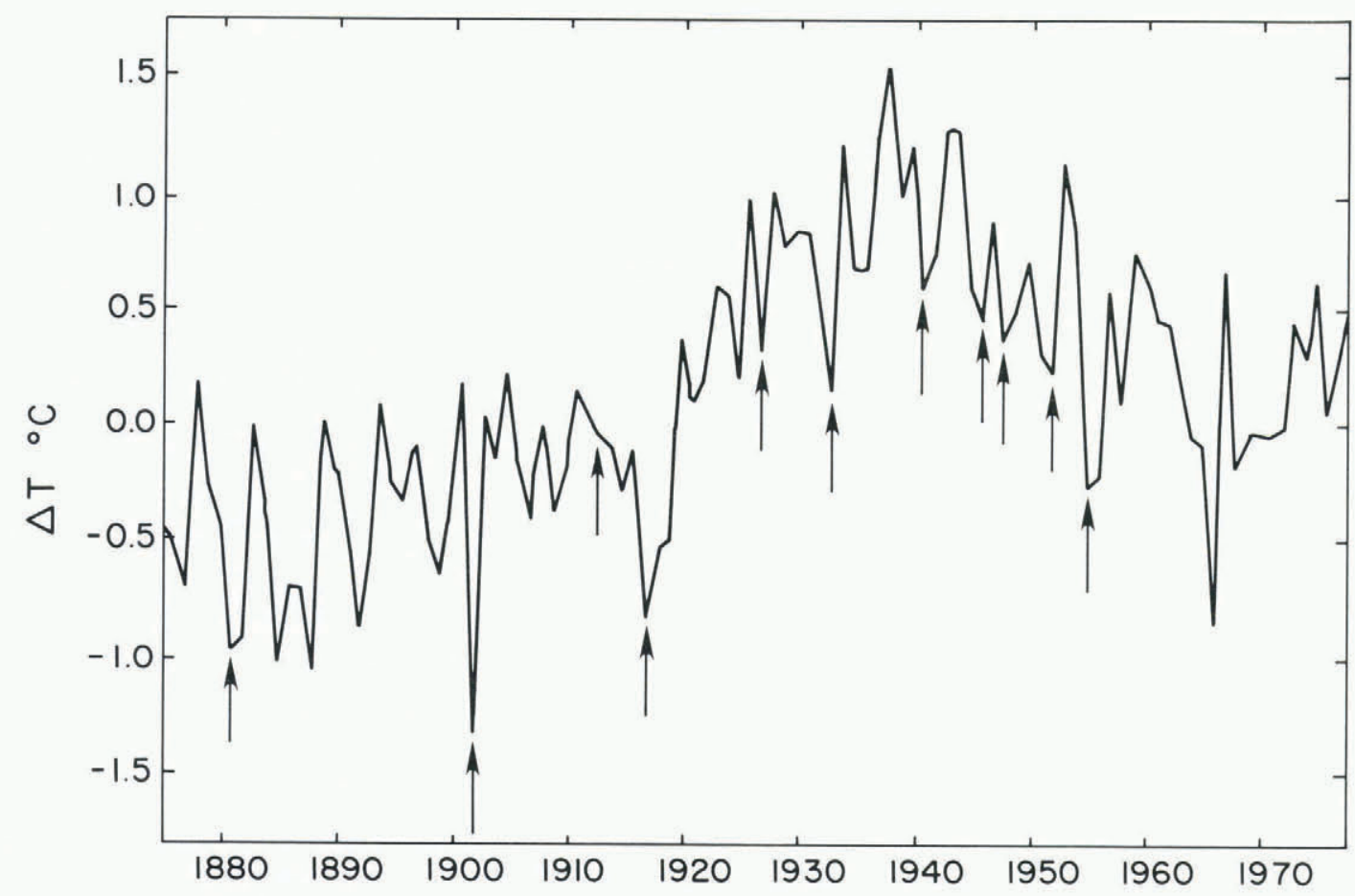

Fig. 1. Average yearly temperature change between $60-90^{\circ} \mathrm{N}$ from 1875 to 1977 ; from Self and others (1981). Arrows present volcanic events observed in $20 \mathrm{D}$ ice.

debris both at our 20 D site (Mayewski and others, 1987) and at Mt. Logan (Holdsworth and others, 1986). These more negative $\delta^{18} \mathrm{O}$ signals in the precipitation imply an immediate local to regional temperature decrease upon the "arrival" of the volcanic aerosol, such as that from the recent El Chichon eruption (Mayewski and others, 1987). This "event" could have produced a $0.5^{\circ} \mathrm{C}$ cooling event during the summer of 1983 in southern Greenland based on oxygen isotope-air temperature calibration (Davidson and others, 1987).

The previously undocumented 1941 event bears some detailed discussion. Although many frost tree ring events in the western USA have been associated with large volcanic events, one of the four major frost tree ring events in this century was in 1941. It has heretofore not been correlated to a known volcanic event (LaMarche and Hirschboeck, 1984). It is curious that one of the largest volcanic "events" observed by us at site $20 \mathrm{D}$ was during this time period. Could this large event have gone unreported due to preoccupation with World War II, as previously suggested by Simkin and others (1981)?

Handler (1986) has recently shown a strong association between stratospheric aerosols and Indian monsoon precipitation. He found that low-latitude aerosols precede below-average precipitation and high-latitude aerosols precede above-average precipitation. He showed that in 1941 there was below-average monsoon precipitation that has not been correlated to a specific volcanic event. Using his arguments and models, the volcanic event recorded by us at $20 \mathrm{D}$ and in the frost tree ring records of the western USA by LaMarche and Hirschboeck (1984) was probably a low latitude $\left(0-25^{\circ} \mathrm{N}\right)$ volcanic eruption. In addition to the 1941 event, our previously unrecorded volcanic events can be utilized to support Handler's (1986) contentions regarding monsoonal variations. Our 1917 and 1942 "events" (Table VI) are probably high-latitude eruptions because they coincide with above-average monsoonal precipitation (Handler, 1986). This is not to say that all monsoonal variations can be interpreted in light of our volcanic data, but that in many cases they can be.

We feel strongly that the technique reported here and in Legrand and Delmas (1987) present the most significant means for detailed quantification of individual volcanic events in the past. In turn, this information can then be used to compare to other historic climatic data in order to assess accurately the role of volcanism on climate.

\section{CONCLUSION}

The results of our glaciochemical measurements conducted on firn and ice samples from southern Greenland indicate that many volcanic eruptions of Northern Hemispheric as well as of global concern are clearly recorded by elevated concentrations of $\mathrm{Cl}^{-}, \mathrm{SO}_{4}^{2-}$ and in some cases also $\mathrm{NO}_{3}^{-}$. Although the majority of these acidic anions has been transported via the stratosphere, Delmas and others (1985a) have argued that due to the closeness of many volcanic centers to Greenland the volcanically produced anions could also be transported in the troposphere. Our data show a strong coincidence of volcanic anion deposition and temperature drops within the latitude band $60-90^{\circ} \mathrm{N}$ for individual volcanic events.

More work of this type in various locations in the Arctic would provide valuable information concerning the type, strength and transport mode of volcanic eruptions. These records could then be better correlated to known climatic records and allow the development of better climatic models. This is particularly true in attempting to assess the role of relatively small but sulfur-rich eruptions (Self and Rampino, 1988).

\section{ACKNOWLEDGEMENTS}

We thank J.V. James (Glacier Research Group) and T. Hinkley (USGS) and B. Koci, K. Kuivinen and S. Watson (Polar Ice Coring Office) for their companionship in the field. In addition, we are indebted to W. Dansgaard, H. Clausen, and N. Gundestrup (University of Copenhagen) for providing the oxygen isotope analyses and valuable insights. Several students in the Glacier Research Group provided assistance in the laboratory. We appreciate the thoughtful review of the original manuscript by J.M. Palais. We thank R. McGill for assistance in the statistical analysis, and A.E. Carey for her critical review of the second draft of the manuscript. This work was supported by an Environmental Protection Agency contract APP-0306-1903 administered through North Carolina State University.

\section{REFERENCES}

Barrie, L.A., D. Fisher, and R.M. Koerner. 1985. Twentieth century trends in Arctic air pollution revealed by 
conductivity and acidity observations in snow and ice in the Canadian high Arctic. Atmos. Environ., 19(12), 2055-2063.

Bradley, R.S. and J. England. 1978. Volcanic dust influence on glacier mass balance at high latitudes. Nature, 271(5647), 736-738.

Cleveland, W.S. 1979. Robust locally weighted regression and smoothing scatter plots. J. Am. Stat. Assoc., 74, 829-836.

Cleveland, W.S. and I.J. Terpenning. 1981. Graphical methods for seasonal adjustment. J. Am. Stat. Assoc., 77, 52-62.

Davidson, C.I., and 6 others. 1987. The scavenging of atmospheric sulfate by Arctic snow. Atmos. Environ., 21, 871-882.

Delmas, R.J., M. Legrand, and G. Holdsworth. 1985a. Snow chemistry on Mount Logan, Yukon Territory, Canada. Ann. Glaciol., 7, 213.

Delmas, R.J., M. Legrand, A.J. Aristarain, and F. Zanolini. 1985b. Volcanic deposits in Antarctic snow and ice. $J$. Geophys. Res., 90(D7), 12,901-12,920.

Devine, J.D., M. Sigurdsson, A.N. Davis, and S. Self. 1984. Estimates of sulfur and chloride yield to the atmosphere from volcanic eruptions and potential climatic effects. $J$. Geophys. Res., 89, 6309-6325.

Hammer, C.U. 1977. Past volcanism revealed by Greenland ice sheet impurities. Nature, 270(5637), 482-486.

Hammer, C.U. 1980. Acidity of polar ice cores in relation to absolute dating, past volcanism, and radio-echoes. $J$. Glaciol., 25(93), 359-372.

Hammer, C.U., H.B. Clausen, and W. Dansgaard. 1980. Greenland ice sheet evidence of post-glacial volcanism and its climatic impact. Nature, 288(5788), 230-235.

Handler, P. 1986. Stratospheric aerosols and the Indian monsoon. J. Geophys. Res., 91(D13), 14,475-14,490.

Herron, M.M. 1982. Impurity sources of $\mathrm{F}^{-}, \mathrm{Cl}^{-}, \mathrm{NO}_{3}^{-}$and $\mathrm{SO}_{4}{ }^{2-}$ in Greenland and Antarctic precipitation. $J$. Geophys. Res., 87(C4), 3052-3060.

Herron, M.M., S.L. Herron, and C.C. Langway, jr. 1981. Climatic signal of ice melt features in southern Greenland. Nature, 293(5831), 389-391.

Holdsworth, G. and E. Peake. 1985. Acid content of snow from a mid-troposphere sampling site on Mount Logan, Yukon Territory, Canada. Ann. Glaciol., 7, 153-160.

Holdsworth, G., H.R. Krouse, and E. Peake. 1986. Relationship between volcanic emission peaks and the oxygen isotope signature in an ice core from the Yukon Territory, Canada. EOS, 67(44), 883.

Hoyt, D.V. 1979. Atmospheric transmission from the Smithsonian Astrophysical Observatory pyrheliometric measurements from 1923-1957. J. Geophys. Res., 84(C8), 5018-5028.

Johnson, D.A. 1980. Volcanic contribution of chloride to the stratosphere: more significant to ozone than previously estimated? Science, 209, 491-493.

Koerner, R.M. and D.A. Fisher. 1982. Acid snow in the Canadian high Arctic. Nature, 295(5845), 137-140.

Koide, M. and E.D. Goldberg. 1985. The historical record of artificial radioactive fallout from the atmosphere in polar glaciers. In Langway, C.C., jr, H. Oeschger, and W. Dansgaard, eds. Greenland ice core: geophysics, geochemistry, and the environment. Washington, DC, American
Geophysical Union, 95-100. (Geophysical Monograph 33.)

LaMarche, V.C., jr and K.K. Hirchboeck. 1984. Frost rings in trees as records of major volcanic eruptions. Nature, 307, 121-126.

Lamb, H.H. 1970. Volcanic dust in the atmosphere; with a chronology and assessment of its meteorological significance. Philos. Trans. R. Soc. London, Ser. A, 266(1128), 425-533.

Lazrus, A.L., R.D. Cadle, B.W. Gandrud, J.P. Greenberg, B.J. Huebert, and W.I. Rose, jr. 1979. Sulf ur and halogen chemistry of the stratosphere and of volcanic eruption plumes. J. Geophys. Res., 84(C12), 7869-7875.

Legrand, M. and R.J. Delmas. 1987. A 220-year continuous record of volcanic $\mathrm{H}_{2} \mathrm{SO}_{4}$ in the Antarctic ice sheet. Nature, 327(6124), 671-676.

Mayewski, P.A., and 7 others. 1986. Sulfate and nitrate concentrations from a south Greenland ice core. Science, 232(4753), 975-977.

Mayewski, P.A., M.J. Spencer, W.B. Lyons, and M. Twickler. 1987. Seasonal and spatial trends in south Greenland snow chemistry. Atmos. Environ., 21(4), 863-869.

Neftel, A., J. Beer, H. Oeschger, F. Zurcher, and R.C. Finkel. 1985. Sulphate and nitrate concentrations in snow from south Greenland 1885-1978. Nature, 314(6012), 611-613.

Pollack, J.B., O.B. Toon, C. Sagan, A. Summers, B. Baldwin, and W. van Camp. 1976. Volcanic explosions and climatic change: a theoretical assessment. J. Geophys. Res., 81(6), 1071-1083.

Rampino, M.R. and S. Self. 1982. Historic eruptions on Tambora (1815), Krakatau (1883), and Agung (1963), their stratospheric aerosols, and climatic impact. Quat. Res., 18(2), 127-143.

Rampino, M.R. and S. Self. 1984. Sulphur-rich volcanic eruptions and stratospheric aerosols. Nature, 310, $677-$ 679.

Sear, C.B., P.M. Kelly, P.D. Jones, and C.M. Goodess. 1987. Global surface-temperature responses to major volcanic eruptions. Nature, 330, 365-367.

Sedlacek, W.A. E.J. Mroz, A.L. Lazrus, and B.L. Gandrud. 1983. A decade of stratospheric sulfate measurements compared with observations of volcanic eruptions. $J$. Geophys. Res., 88(C6), 3741-3776.

Self, S. and M.R. Rampino. 1988. The relationship between volcanic eruptions and climatic change: still a conundrum? EOS, 69, 74-86.

Self, S. M.R. Rampino, and J.J. Barbara. 1981. The possible effects of large 19th and 20th century volcanic eruptions on zonal and hemispheric surface temperatures. J. Volcanol. Geotherm. Res., 11, 41-60.

Simkin, T., L. Siebert, L. McClelland, D. Bridge, C. Newhall, and J.H. Latter. 1981. Volcanoes of the world. Strandsburg, PA, Hutchinson Ross.

Stothers, R.B. 1984. The Great Tambora eruption in 1815 and its aftermath. Science, 224, 1191-1198.

Symonds, R.B., W.I. Rose, and M.H. Reed. 1988. Contribution of $\mathrm{Cl}^{-}$and $\mathrm{F}^{-}$bearing gases to the atmosphere by volcanoes. Nature, 334, 415-418.

Woods, D.C., R.L. Chuan, and W.I. Rose. 1985. Halite particles injected into the stratosphere by the $1982 \mathrm{El}$ Chichon eruption. Science, 230, 170-172. 